\title{
The Orthodox Jewish Community and the Coronavirus: Halacha Grapples with the Pandemic
}

\author{
Mark L. Trencher ${ }^{1}$ (D)
}

Received: 28 September 2020 / Accepted: 13 July 2021 / Published online: 19 August 2021

(C) The Author(s), under exclusive licence to Springer Nature B.V. 2021

\begin{abstract}
Many general population surveys have been conducted relating to the coronavirus/ COVID-19. Some have reported on small samples of Jewish respondents, but issues specific to Judaism have not been well explored. This paper provides findings from the first broad coronavirus-related survey of the U.S. Orthodox Jewish community, conducted in May 2020 among 502 Jewish respondents who resided in the United States, self-identified as Orthodox Jews, and indicated whether they were Modern Orthodox or Haredi ("Ultra-Orthodox"). The survey broadly probed the impact of the pandemic through the lens of Jewish individual and communal attitudes, behaviors and practices, exploring such issues as people's health, finances, Jewish prayer and religious study, synagogues and their programs, what services their communities and its Jewish organizations are offering, the extent to which they avail themselves of these services and how they are perceived, changes in the perceived value of Jewish communal connection, and many other aspects, including how people assess the pandemic's impact on their overall "feelings of Jewishness." While many communal changes arising from the pandemic will prove to be transitory, others may become more permanent or, at the very least, create introspection with respect to normative religious observance. This paper references findings relating to the former, while focusing on the latter. Thus, we focus on and report survey findings relating to how the Orthodox community has melded its adherence to Halacha (Jewish law) and tradition with the need for change and flexibility required to deal safely with the pandemic. We will also share some of the communal views that have arisen on how such changes might play out in the years ahead.
\end{abstract}

Keywords Survey $\cdot$ COVID $\cdot$ Coronavirus $\cdot$ Pandemic $\cdot$ Jewish $\cdot$ Orthodox $\cdot$ Modern Orthodox · Haredi

Mark L. Trencher

mark@nishmaresearch.com

http://nishmaresearch.com

1 Nishma Research, West Hartford, CT, USA 


\section{Introduction}

\section{Orthodox Judaism-An Under-Studied Population}

While much communal research is conducted in the broad U.S. Jewish community, much less research is conducted among the Orthodox and, in particular, within its Haredi segment. A recent Pew Research Center study (Pew Research Center's Jewish Americans in 2020; May 11, 2021, https://www.pewforum.org/2021/05/11/jewish-americans-in-2020/)_-is illustrative. Starting with statistical data, Pew's national cross-sectional, address-based sampling survey (methodologically a state-of-the art survey) drew 4718 respondents, providing a $95 \%$ margin of error of $\pm 3 \%$. Because the Orthodox community is relatively small, Pew's sample of the Orthodox was 430, providing a much larger $95 \%$ margin of error of $\pm 9 \%$. Diving further, if we extracted data for the three sub-segments of Orthodoxy-Hasidic, Yeshivish and Modern Orthodox Jews, the margins of error would be between $\pm 15 \%$ and $\pm 17 \%$ for the segments. And, of course, comparisons of male and female, across age categories, by educational levels attained, are all difficult given the small sample sizes.

Additionally, questions relevant to the Orthodox are different from those asked of the large American Jewish community, reflecting Orthodoxy's different practices, beliefs and priorities. While surveys like Pew or those that are Federation-sponsored might not ask about concerns relating to the cost of maintaining a kosher kitchen or whether people pray in synagogue on a daily basis, such questions might be appropriate in a survey of the Orthodox community.

More recently, surveys focusing on areas such as political views (such as Ben Sales and Laura Adkins, “I think it's Israel': How Orthodox Jews became Republicans," Jewish Telegraphic Agency, February 13, 2020; https://jewishworldnews. org/i-think-its-israel-how-orthodox-jews-became-republicans/) and handling of the Coronavirus pandemic (as discussed in this paper) have highlighted sharp differences between the Orthodox community and the rest of American Judaism.

While the American Orthodox community is relatively small, it seems to disproportionately affect how the public perceives the Jewish community (Cathryn Prince, "Under attack, US ultra-Orthodox are misunderstood, "terrified",; The Times of Israel, February 26, 2020. https://www.timesofisrael.com/jewish-academic-underattack-us-ultra-orthodox-are-misunderstood-terrified/). Our hope is that this paper will contribute to a growing body of literature dealing with the historically understudied Orthodox community, and will spur researchers to develop methodologies to reach this community and to conduct quality research to fill our knowledge gaps relating to it.

\section{Methodology}

Many broad population surveys have been conducted relating to the coronavirus pandemic (Kaiser Family Foundation Coronavirus (COVID-19) and Pew Research Center Coronavirus Disease). Few have broken out findings specific 
to the Jewish community, and our objective in conducting this research was to explore a broad set of issues specific to the Orthodox Jewish community.

The survey reports and related information (including survey respondent demographic data) that we draw upon are publicly available (Trencher 2020 and Berman Jewish Databank). Additionally, we cite a few items derived from more recent research (conducted since the mid-2020 Nishma survey) and more recent observations.

This was an "opt-in" online survey that took about $15 \mathrm{~min}$ to complete and was conducted May 4-19, 2020. We reached Jews residing in the U.S. through their Orthodox synagogue rabbis who are members of the Rabbinical Council of America, the National Council of Young Israel, and the International Rabbinic Fellowship. A total of 502 respondents self-identified as Orthodox and further indicated whether they fall within the Modern Orthodox or Haredi ("Ultra-Orthodox") camps within Orthodoxy. The findings presented are based on these 502 respondents.

We refer to our sample of 502 as the "respondents" with the understanding that the extent to which they represent the larger community is not knowable and that we therefore avoid inference to the larger population, for several reasons. For one thing, there is no "profile" of the Orthodox community, based on an adequately large sample, to which our respondents can be compared to ascertain their representativeness. The relative shares of Modern Orthodox and Haredi respondents in our sample-approximately 430 and 70, or $86 \%$ and $14 \%$, respectively-differ from their representation in the population-estimated at $37 \%$ and $63 \%$, respectively (Trencher 2018). To adjust for this, data labeled in this report as "Orthodox Total" are derived by weighting the groups so as to reflect their representation in the population.

Our sample of Haredi Jews may be atypical. The Haredi have an insular approach to society and are significantly more difficult to reach for purposes of research than are the Modern Orthodox. The Haredi divide into two groups: Yeshivish and Hasidic. The Hasidic group is larger than the Yeshivish group, many have Yiddish as their primary language, and they are even more isolated from secular society than the Yeshivish, e.g., many do not have computers or smartphones, do not watch TV or read secular newspapers or magazine, all activities that are found much more often in the Yeshivish world. This insularity impedes their accessibility, ability and willingness to participate in research studies. Our small sample of Haredi respondents is therefore likely less insulated than all Haredi Jews (e.g., English-speaking, having Internet access, more often being a member of a synagogue whose rabbi is affiliated with one of the non-Haredi organizations cited above, etc.). Research within the Yiddish-speaking, more insulated Haredi community remains a challenge.

The sample respondents come from a diverse range of backgrounds in terms of the religious orientation, financial status, health, age, etc. Despite the challenges inherent in reaching and surveying a small community, the study uncovers intriguing findings that are distinctive to the Jewish population. It is our hope that these findings will help to inform future research.

While the survey developed quantitative, statistical data, we believe there is much to be learned from respondents' verbatim responses. To that end, the survey included many open-ended questions, giving respondents the opportunity to express 
themselves more fully. An illustrative sample of responses relevant to the topics being explored are included in this paper.

The full survey (Trencher 2020) covered much ground across a range of issues affected by the pandemic, including coronavirus awareness, concerns, health risk status, testing, personal safety and social distancing, financial effects, satisfaction with policymakers, and children's education, as well as differences across demographic groups, e.g., older vs. younger, educational levels, etc. Religious matters were just one of the sets of issues and this paper focuses on the Orthodox religious aspects and impacts.

\section{Halacha Grapples with the Pandemic}

Much of Orthodox Jewish day-to-day life is guided by Halacha-Jewish law, based on passages in the Torah and analyses by rabbis over the centuries, as well as customs. Halacha requires such activities as daily prayer (morning and evening) with a minyan, a quorum of at least ten other males, and the study of religious topics, which is generally seen as a group, interactive activity (e.g., learning with a study partner in a yeshiva setting). Additionally, Orthodoxy is very much a communally centered group, and a very common practice is to celebrate joyous occasions (e.g., weddings) or to observe sad ones (e.g., funerals) with very large groups in attendance. So it can be seen that the pandemic-with the required social distancingcould affect such observances.

Halacha provides some leeway and opportunities for flexibility, depending on circumstances, and rabbinic guidance is often sought in dealing with unusual situations. Additionally, there are circumstances involving danger to human life where halachic flexibility is not just permitted-it is required.

The coronavirus pandemic has required changes in many normative practices. Some measures, such as social distancing, have been implemented in the Jewish community during some past pandemics, but others, such as the use of technology, are new.

This paper does not explore the nature of halachic deliberations that underlie changes that have been made or explored; there has been a growing body of rabbinic literature exploring and explaining why halachic changes have occurred, and many rabbis have been considering whether and how to use technology, how to prioritize and balance communal needs and safety with religious obligations (Klapper 2020). Our focus will be on changes that have been enacted, the extent to which people have availed themselves of halachic leniencies, satisfaction or lack thereof, and views regarding possible post-pandemic retention of some of the changed practices.

\section{The Cornerstones of Orthodox Jewish Life}

In developing the coronavirus survey questionnaire, we started by drawing upon what previous research has shown to be the most important elements of Orthodox Jewish life. For one thing, when Orthodox Jews have been asked what gives "the most satisfaction, joy or meaning to (your) Jewish life," the most frequent response 
by a substantial margin was community and sense of belonging. Also high on the list were connection to and attendance at synagogue, prayer (davening, tefillah), study of Jewish topics (learning, shiurim/classes), and various aspects relating to a sense of spirituality and connection to God. Figure 1 shows the most important aspects/ components of Orthodox Jewish life, as identified in a 2017 survey of nearly 4000 Modern Orthodox Jews (Trencher 2017).

Of the key aspects/components of Orthodox Jewish life, several seem to be susceptible to disruption by a pandemic:

- Community, sense of belonging-It is a tightly-knitted physical community comprised of people who live in close proximity and interact often in synagogue as well as in their day-to-day lives. Typical survey responses included: "I think community is what gives me the greatest happiness. Being around other likeminded people who share a Torah lifestyle together is where it all starts." "I love my religion and community. I am blessed to be able to raise my children in such a committed community, both synagogue and schools." (Sample verbatim responses in this and the following bullet points derive from Trencher 2020.)

- Shabbat-In addition to ritual observance of the Sabbath day, key elements are synagogue attendance and having communal meals or inviting guests to one's home for a meal. Synagogue attendance—particularly on Shabbat—is very high among Orthodox Jews, e.g., "Most important to me is that as a member of my Modern Orthodox community, I am a part of Klal Israel, the Jewish people. By going to Shul on Shabbat/holiday eves or Shabbat/holiday mornings, by being

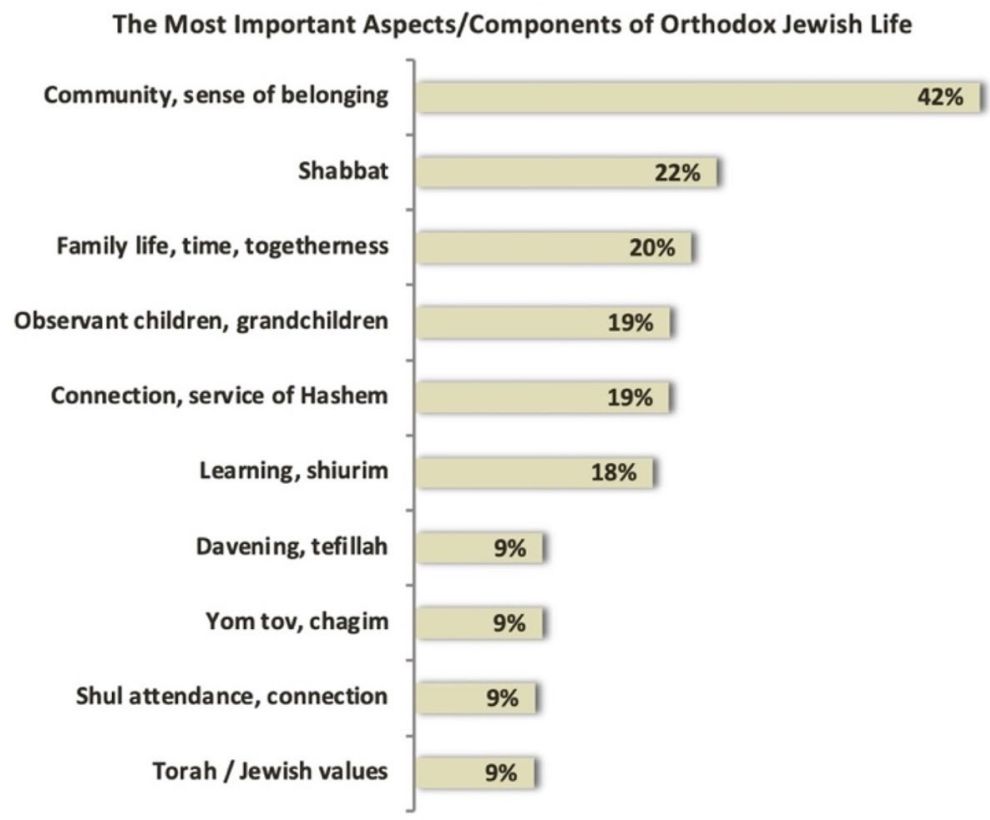

Fig. 1 The most important aspects/components of Orthodox Jewish life 
there I am re-affirming that I am a part of the Jewish people." The pandemic required the shuttering of the synagogue for many months and slowly permitted openings, with social distancing imposed. How did people deal with this?

- Davening, tefillah-Group prayer is the core purpose of the synagogue, requiring a quorum of attendees (minyan). Individual (at home) prayer is not uncommon but is seen as a much less-preferred alternative.

- Family life, time, togetherness-Multi-generational families often assemble on Shabbat and the Chagim (holidays). An entire annual cycle of family get-togethers-Passover/Pesach family get-togethers, in which $70 \%+$ of American Jews participate (Lauren Markoe, "Passover, most beloved Jewish holiday, explained. Lauren Markoe," Religion News Service, April 22, 2016), Shavuot, Rosh Hashanah, Yom Kippur, Sukkot, Chanukah and Purim-have all been observed in much-altered form. While the survey that forms the primary basis of this article was conducted after Passover, and other holidays had not yet occurred, they have all been affected in the synagogue (lower attendance, altered services).

- Observant children, grandchildren-Respondents experience joy from seeing children carrying on the Jewish traditions, and this seems less affected by the pandemic. It may even be argued that increased use of technology has given families more opportunities to "see each other."

- Connection, service of Hashem-This touches on elements of faith; while seemingly an individualistic expression, we shall explore whether and how the pandemic has affected faith. For example, some segments of the Orthodox community (Haredi) have experienced much tragedy due to high incidence of COVID and resulting deaths. Will any impacts of this manifest themselves when asked how the pandemic has affected them Jewishly?

- Torah study-The community provides many group Torah study opportunities, on Shabbat and weekdays, including lectures as well as programs for smaller group study. Historically, much of Torah study has been done in schools and synagogues. We will explore whether the pandemic has altered this activity and how well people have adapted to it.

- Technology Overall-The pandemic has forced the introduction of technology and other changes. We will explore community thoughts relating to the possible retention of some of the new media and methodologies.

\section{Changes in the Synagogue (the "Shul")}

The Orthodox community is small and, because driving on Shabbat is prohibited, its members live in close proximity to their synagogue and to each other. The shul is the cornerstone of Orthodox life, and members of the community interact with each other frequently at synagogue, in prayer, classes, youth programs and social activities (My Jewish Learning, "The Synagogue." https://www.myjewishlearning.com/ article/the-synagogue/, Accessed May 22, 2021).

As shown in Table 1, in pre-pandemic times the vast majority of men (84\%) attended shul for Shabbat morning prayer, as did a majority (52\%) of women (Trencher 2017). Men often attended the other Shabbat services as well as some 
Table 1 Synagogue attendance-pre-pandemic

\begin{tabular}{lll}
\hline$\%$ attending always or almost always & Men $(\%)$ & Women $(\%)$ \\
\hline Friday night/erev Yom Tov night & 61 & 11 \\
Shabbat/Yom Tov morning & 84 & 52 \\
Shabbat/Yom Tov mincha/maariv & 54 & 9 \\
Weekday morning & 33 & 2 \\
Weekday mincha/maariv & 21 & 1 \\
\hline
\end{tabular}

weekday services. These data are for the Modern Orthodox community. While comparable statistical data for the Haredi community are not available, we believe based on much observation that Haredi attendance by men is higher than that of Modern Orthodox, especially on weekdays. On the other hand, attendance by Haredi women is substantially lower than that of Modern Orthodox women.

As shown in Table 2, as social distancing became the new normal, the Orthodox community was reasonably compliant, with $80 \%$ leaving home only for necessary items (although it is likely that Haredi Jews found group prayer more often to be "necessary" than do Modern Orthodox); and 85-90\% maintaining distance from others (Trencher 2020, p. 11).

As awareness of the pandemic and its potential severity surfaced, the Modern Orthodox community was the first segment of Orthodoxy to take public action. This was evidenced by the pronouncements on March 12, 2020, of the Rabbinical Council of Bergen County (RCBC), a group of predominantly Modern Orthodox rabbis in the Teaneck, New Jersey area (a suburb of New York City). The RCBC's dramatic announcements (Rabbinican Council of Bergen County. "COVID-19 Updates," https://www.rcbcvaad.org/important-updates) essentially shut down the entire Orthodox community in the Teaneck area.

Prayer was forced to leave the synagogue, as were the study of Jewish topics and synagogue-based social programs. We do not have data on compliance among synagogues-how many shut their doors, and when-but we do know that many synagogues started to use technology as a means to conduct "virtual" prayer and learning.

\section{Synagogue Offerings Change}

As shown in Table 3, two-thirds of Modern Orthodox respondents indicated that their synagogue was offering online weekday group prayer (Shabbat group prayer

Table 2 Personal safety and social distancing

\begin{tabular}{llll}
\hline Multiple responses & Orthodox total (\%) & $\begin{array}{l}\text { Modern Orthodox } \\
(\%)\end{array}$ & Haredi (\%) \\
\hline Only leave home for necessary items & 80 & 79 & 81 \\
Keep a distance of six feet from people & 86 & 89 & 85 \\
Stopped meeting with people in-person & 64 & 70 & 61 \\
\hline
\end{tabular}


Table 3 Jewish congregation services and offerings

Orthodox total Modern Ortho- Haredi (\%)

(\%) $\quad \operatorname{dox}(\%)$

$\begin{array}{lccc}\text { Member of a Jewish congregation } & 98 & 97 & 99 \\ \text { Among synagogue members: which of these services } & \text { is } & \text { your congregation offering? } & \\ \text { Online group prayer services } & 38 & 67 & 20 \\ \text { Online classes } & 82 & 94 & 75 \\ \text { Online social programs } & 48 & 69 & 36 \\ \text { Assistance with food or other delivery } & 58 & 71 & 51 \\ \text { Checking up on members by phone or other means } & 70 & 74 & 68\end{array}$

was not offered online, due to halachic prohibitions relating to the use of electricity), over $90 \%$ were offering online classes, and about $70 \%$ were conducting online social programs (Trencher 2020, p. 16). All forms of online offerings were less common in the Haredi community. Online prayer and social programs were offered much less often (20\% and $36 \%$, respectively), while online learning was offered somewhat less often (75\%). Additionally, more than two-thirds of respondents indicated that their synagogues were checking up on members by phone or other means, and this occurred across all of Orthodoxy.

\section{Online Offerings-Attendance and Satisfaction}

As shown in Table 4, a bit more than one-third of Modern Orthodox attended online prayer three or more times in a four-week period (Trencher 2020, p. 17). In comparison to typical pre-pandemic Modern Orthodox synagogue attendance (see Table 1 above), this does not represent strong adoption of online services at the individual level. Synagogues were offering it, but not a lot of members were attending these services. Among the Haredi, barely any synagogues offered online prayer (not enough for the responses to have any level of statistical reliability).

Online classes and/or social programs were attended more often than online prayer, with 39-45\% having attended three or more such programs in the past fourweek period.

Among the Modern Orthodox who had attended online prayer, about one in four (28\%) said they were very satisfied, although more than two-thirds (70\%) said they were either very or somewhat satisfied. It appears that those who tried the online offerings were moderately satisfied with the experience, although they represented a minority of the community.

Since this survey was conducted, most synagogues have restarted their group prayer services, although with restrictions in place (in terms of number of participants, distancing, behaviors, etc.). Still, a significant percentage of the Orthodox community has experienced a lengthy detachment from traditional prayer.

Online services, especially prayer, are quite a departure from the pre-pandemic norm; a few of the verbatim comments illustrate respondents' feelings on this issue: 
Table 4 Participation and satisfaction with online offerings

\begin{tabular}{|c|c|c|c|}
\hline \multirow{3}{*}{$\begin{array}{l}\text { Non- } \\
\text { Orthodox } \\
(\%)\end{array}$} & \multicolumn{3}{|c|}{ Orthodox } \\
\hline & \multicolumn{3}{|c|}{$\begin{array}{l}\mathrm{NM}=\text { Not meaningful due to } \\
\text { small Haredi sample }\end{array}$} \\
\hline & All & $\begin{array}{l}\text { Modern } \\
\text { Orthodox } \\
(\%)\end{array}$ & Haredi (\%) \\
\hline
\end{tabular}

In the last four weeks, about how often in total have you participated in online group prayer services? (among those whose synagogue offers it)

\begin{tabular}{|c|c|c|}
\hline Five or more times & 28 & NM \\
\hline Three or four & 25 & \\
\hline Once or twice & 24 & \\
\hline Haven't participated & 23 & \\
\hline
\end{tabular}

How satisfied have you been with online group prayer services? (among those who have participated)

$\begin{array}{llll}\% \text { Very satisfied } & 29 & \text { NM } & 28 \\ \% \text { Somewhat satisfied } & 52 & & 42 \\ \text { Total Satisfied } & 81 & & 70\end{array}$

In the last four weeks, about how often in total have you participated in online classes or social programs? (among those whose synagogue offers it)

\begin{tabular}{lllll} 
Three or more times & 34 & 43 & 39 & 45 \\
Once or twice & 25 & 29 & 31 & 28 \\
Haven't participated & 41 & 28 & 30 & 27 \\
\hline
\end{tabular}

$N M$ Not meaningful due to small sample size

- "I feel a greater sense of the strength of my Jewish community which quickly responded... on-line prayer groups, learning groups, exercise groups and social groups were established free to all."

- "My wife and I have attended more on-line study sessions... and tefillot than in the past."

- "The incredible importance of allowing people to say Kaddish and hold Seders over Zoom. It's pikuach nefesh (preservation of human life) to break down isolation."

- "We have seen that we can still be a community even when we are not able to be near one another. Zoom classes are something we should consider continuing."

Orthodoxy recognizes that group prayer is powerful in a way that private prayer by oneself at home is not. As one prominent Modern Orthodox rabbi noted, "Despite shuls having re-opened in safe and cautious ways, only a fraction of those 'eligible,' those not considered 'high risk,' have come back... There are many reasons people came to shul, all legitimate and meaningful, even if not equally so. Some, of course, come to connect and open their hearts 
Table 5 Assessment of synagogue support
Table 6 Assessment of overall Jewish community support

\begin{tabular}{llll}
\hline & $\begin{array}{l}\text { Orthodox } \\
\text { total (\%) }\end{array}$ & $\begin{array}{l}\text { Modern } \\
\text { Orthodox (\%) }\end{array}$ & Haredi (\%) \\
\hline Very satisfied & 51 & 54 & 49 \\
Somewhat satisfied & 27 & 27 & 27 \\
Total satisfied & 78 & 81 & 76 \\
Somewhat dissatisfied & 7 & 8 & 6 \\
Very dissatisfied & 6 & 2 & 8 \\
Not relevant to me & 6 & 5 & 7 \\
Don't know & 3 & 4 & 3 \\
\hline
\end{tabular}

\begin{tabular}{llll}
\hline & $\begin{array}{l}\text { Orthodox } \\
\text { total (\%) }\end{array}$ & $\begin{array}{l}\text { Modern } \\
\text { Orthodox (\%) }\end{array}$ & Haredi (\%) \\
\hline Very satisfied & 54 & 49 & 57 \\
Somewhat satisfied & 32 & 36 & 29 \\
Total satisfied & 86 & 85 & 86 \\
Somewhat dissatisfied & 5 & 5 & 6 \\
Very dissatisfied & 2 & 2 & 3 \\
Not relevant to me & 3 & 3 & 3 \\
Don't know & 4 & 5 & 3 \\
\hline
\end{tabular}

to Hashem, others to socialize, others to be part of community, yet others to enjoy kiddush... The awful unintended consequence is missing so many of our beloved members... While I am sure that the people who are not returning to shul are davening (praying) either at home or elsewhere, I believe the absence of a desire to come back to a shul that lacks anything other than davening is a sign that some people are struggling with connecting to davening itself" (Rabbi Efrem Goldberg, Young Israel of Boca Raton, cited in Polack 2020.

Despite the tepid response to online prayer and classes, respondents were quite satisfied with the overall support of their synagogue during the pandemic. As shown in Tables 5 and 6, about $80 \%$ of Orthodox Jews were very or somewhat satisfied with their synagogue's support, with little variation between the Modern Orthodox and Haredi wings. Satisfaction was even higher-in the $85 \%$ range-when looking at the support provided by the Jewish community as a whole (synagogues, Jewish community centers, Federation, other Jewish organizations, etc.) (Trencher 2020, p. 18).

Typical of respondents' verbatim responses are: "I honestly have been so impressed by everything I have seen come out from schools, shuls, etc." and "I have seen synagogue communities working hard to assure their members are not socially isolated, even though we are physically isolated, and assuring that vulnerable members have food, medications, etc., that they need." 
Table 7 Views on the value of synagogue membership

\begin{tabular}{llll}
\hline Among current synagogue members & $\begin{array}{l}\text { Orthodox total } \\
(\%)\end{array}$ & $\begin{array}{l}\text { Modern Ortho- } \\
\text { dox (\%) }\end{array}$ & Haredi (\%) \\
\hline $\begin{array}{l}\text { I now see more value in synagogue membership } \\
\text { My views on the value of synagogue membership }\end{array}$ & 28 & 23 & 31 \\
$\quad$ have not changed & 39 & 71 & 67 \\
\begin{tabular}{l} 
I now see less value in synagogue membership \\
\hline
\end{tabular}
\end{tabular}

\section{Value of Synagogue Membership}

As shown in Table 7, the perceived value of being a synagogue member has held its own (Trencher 2020, p. 19). More than two-thirds of synagogue members said their views on the value of synagogue membership haven't changed, and the vast majority whose views have changed said they saw more value in being a synagogue member.

\section{Incidence of Broader Synagogue/Communal "Outreach"}

Given the shift to virtual programming (via Zoom, etc.), we probed the extent to which people reached out more broadly than they had in the past- to institutions outside of their local synagogue/community-for Jewish classes, information, spiritual guidance and participation. As shown in Fig. 2, a notable minority (35-40\%) have done so (Trencher 2020, p. 18), as illustrated by some of the verbatim responses:

- "I am deeply involved in Jewish learning outside my congregation, and feel nourished by my connections and tradition."

- "I really appreciate the access to religious leaders outside of my city and I feel like that has only been made possible now that everyone has taken to online classes."

\section{Feelings of Isolation}

As has been noted, Orthodox Jewry is very much a social, communal experience and it is therefore not surprising that about two-thirds experience a sense of isolation. As shown in Fig. 3, about 20\% experience it to a great extent, and another 45-50\% experience it to some extent-with little variation among the Orthodox groups (Trencher 2020, p. 12).

A few of the verbatim comments illustrate respondents' feelings on this issue:

- "I think, even though, close friends and neighbors are no longer dropping in or coming for Shabbat, we've developed a stronger bond from the isolation. We 


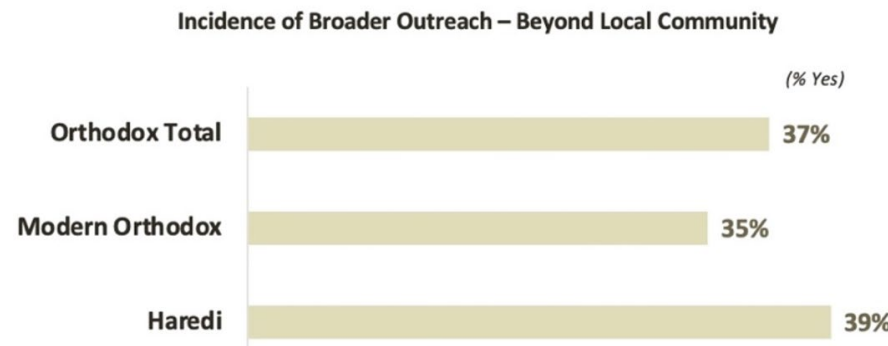

Fig. 2 Incident of broader outreach-beyond local community

simply keep in touch...differently... We've come to appreciate more deeply our friendships...due to the separation."

- "I feel less inspired while isolated and not able to attend events in person."

- "The community is now caring about so many issues of singles being isolated and mental health (but) I don't feel any less Jewish in isolation."

- "It's really lonely living alone during this time."

Of course, the Jewish community is not alone. Much has been written about the sense of isolation and loneliness created by the pandemic in society generally, including the fact that the young are more affected than seniors (AARP, "Pandemic Has Created Loneliness Epidemic, New Report Shows." October 8, 2020; https:// www.aarp.org/home-family/friends-family/info-2020/isolation-survey-coronavirus. html).

Extent of Feelings of Isolation

\begin{tabular}{|c|c|c|c|c|}
\hline $\begin{array}{l}\text { Orthodox } \\
\text { Total }\end{array}$ & $20 \%$ & $48 \%$ & $27 \%$ & $5 \%$ \\
\hline $\begin{array}{l}\text { Modern } \\
\text { Orthodox }\end{array}$ & $21 \%$ & $45 \%$ & $28 \%$ & $6 \%$ \\
\hline Haredi & $19 \%$ & $50 \%$ & $26 \%$ & $4 \%$ \\
\hline
\end{tabular}

Fig. 3 Extent of feelings of isolation 


\section{Impact of the Pandemic on How People Feel "Jewishly"}

Early in the pandemic (April 2020), the Pew Research Center (https://www.pewre search.org/fact-tank/2020/04/30/few-americans-say-their-house-of-worship-is-openbut-a-quarter-say-their-religious-faith-has-grown-amid-pandemic/) reported that "Jews ... are more likely (than members of other religions) to say their faith hasn't changed much (69\%) or that the question isn't applicable to them because they are not religious (22\%), than they are likely to say their faith has grown stronger during the outbreak (7\%).

However, one journalist noted the possibility that "few Jews responded positively to the 'faith' question because the question's wording referenced 'religious faith', a terminology that tends to be less common among Jews than among Christians (Ben Sales. Jewish Telegraphic Agency, "1 in 4 Americans say the pandemic has strengthened their faith. For Jews, it's 7\%," May 1, 2020. https://www.jta.org/quick-reads/1in-4-americans-say-the-pandemic-has-strengthened-their-faith-for-jews-its-7).

In our survey, we chose to phrase this question more generally, and asked: "Have your experiences since the start of the coronavirus pandemic affected how you feel 'Jewishly'? This might include such aspects as your sense of connection, community, involvement, spirituality, etc.?").

The responses suggest that "feelings of Jewishness" were indeed affected. As seen in Table 8 (Trencher 2020, p. 20), very few respondents (3\%) stated that their "feelings of Jewishness" had weakened during the pandemic, while more say their feelings had strengthened (22\% of Modern Orthodox and a notably higher 38\% among Haredi).

Table 8 Pandemic experiences effect on how people feel "Jewishly"

\begin{tabular}{lccr}
\hline My "Jewish feelings" overall ... & Orthodox total (\%) & $\begin{array}{l}\text { Modern Orthodox } \\
(\%)\end{array}$ & Haredi (\%) \\
\hline Have become strengthened & 32 & 22 & 38 \\
Have become weakened & 3 & 5 & 1 \\
$\begin{array}{l}\text { Are mixed; in some ways strengthened, but } \\
\quad \text { in some ways weakened }\end{array}$ & 16 & 18 & 15 \\
No real change & 49 & 55 & 46 \\
\hline
\end{tabular}

Some of the common themes relating to respondents' changed "feelings of Jewishness" were as follows:

Among those who responded: "No real change in my 'Jewish feelings.",-An oft-stated theme is that one's Jewishness is so strong that even something as significant as the pandemic does not affect it. Sample comments: 
- "My primary Jewish feelings are between myself and G-d and therefore not subject to change based on community involvement."

- "My Jewish feelings are solid and 'built in' and not dependent on whether I am home or alone or on zoom online or physically present at a Jewish institution or among other Jewish people physically etc."

- "I've always been a very spiritual person, with great faith in Hashem. That hasn't changed. I don't feel any more or less connected to my community. I probably talk to friends more than I used to, but I don't feel like anything has really changed."

- "This is part of Jewish life. We go thru tough times, we move on."

Among those who responded: "My 'Jewish feelings' overall have become strengthened during the pandemic."-Connections to the Jewish community-local and virtual - are often seen as have been strengthened. People are taking advantage of online offerings and "time at home" to engage more in Jewish rituals and practices. People are proud that their communities are functioning and assisting so many. Sample comments:

- "I see that there are more people who might be able to participate at a distance in synagogue functions easily from their homes if they have the need, using virtual meetings."

- "I just feel awed by the moral leadership from our rabbi in particular, and I just have this powerful sense of pride that we as a community are ... showing such respect for Halacha and Jewish tradition."

- "Greater appreciation for Jewish community life and synagogue services."

- "Hashem is in control and He is leading us somewhere, even though it is not clear to us or to me personally right now. I want to grow and do His Will."

Among those who responded: "My 'Jewish feelings' are mixed; in some ways strengthened, but in some ways weakened"-Some respondents need the physical interactions in order to better maintain their connection. A few were "turned off" by decisions/activities that occurred in their community. Sample comments:

- "My sense of being part of my immediate Jewish community has been somewhat weakened since we can't go to events that usually connect us. ... Online events (are) just not a substitute for the relaxed socializing that happens in person."

- "The reaction of my fellow Jews has both horrified me and delighted me."

- "Not being in shul and having human direct interaction has weakened my Jewish feeling. But Jewish feelings are strengthened by the outreach of the shul and community to those in need."

Among those who responded: "My 'Jewish feelings' overall have become weakened during the pandemic - The factor most mentioned is the missing of physical community/services. Some are bothered by unanswerable theological questions, i.e., why is God creating these challenges and tragedies? Sample comments: 
- "Community is necessary for many parts of davening especially on Shabbos. It isn't the same."

- "Living alone and Struggling with loneliness."

- "I find it difficult under the current circumstances to see that everything is for the best. I feel disconnected from G-d."

\section{Modern Orthodox Views Emerging from the Pandemic}

Orthodoxy is guided by Halacha, Jewish law, and the pandemic brought a flurry of questions (Harris, Ben). While the Modern Orthodox community is accustomed to technology and social media, the pandemic brought increased technologies to the community, notably those synagogues that had online prayer and other halachic flexibilities, given the health risks. But the questions were not limited to new adoption of technologies. They covered an enormous range of changes in Jewish practices.

We asked Modern Orthodox respondents whether they felt that their rabbis should consider adopting some of the enacted flexibilities after the pandemic. As shown in Fig. 4, less than one-third (29\%) agreed that rabbis should consider more halachic flexibility in areas of technology. A plurality (46\%) were opposed to this, and the rest (25\%) were not sure (Trencher 2020, p. 23).

A sample of the verbatim comments on technology as well as general advice that Modern Orthodox might give to their rabbis and communal leaders is illustrative:

\section{Modern Orthodox Desire for Future Halachic Flexibility}

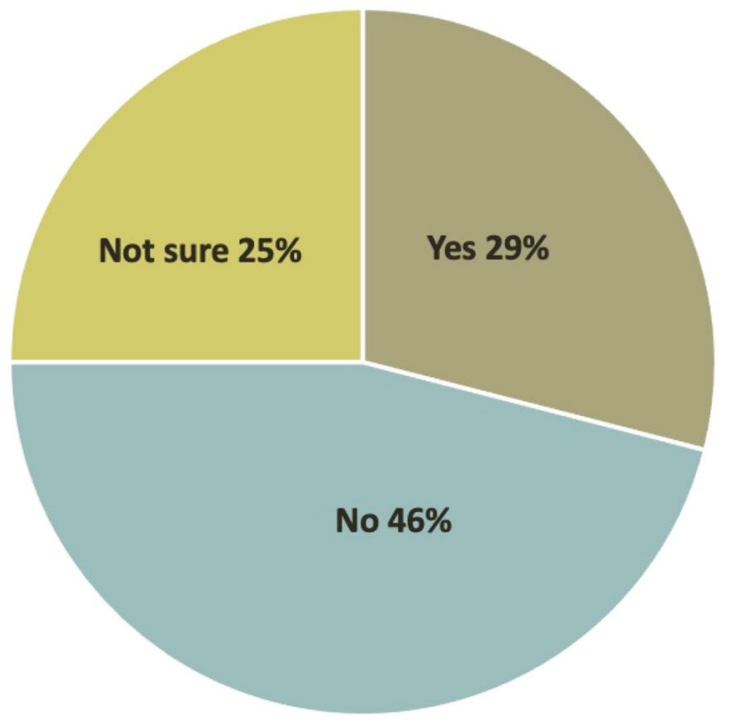

Fig. 4 Modern Orthodox desire for future Halachic flexibility 
- "Religious leaders are working really hard to help people who are isolated during this pandemic. When shuls re-open, I encourage clergy to think about how to be more inclusive of people who can't physically attend. Perhaps they can continue livestreaming events and classes."

- "I have to commend all denominations for adjusting and/or modifying what are called rules, laws, traditions, etc. to meet the needs of our people yet within the accepted practices ... except for those sects that continue to defy wisdom and put health and survival second to their interpretation of the will of G-d."

- "I am fearful that ... people might decide that they're fine without traditional Jewish observance. I would urge that the necessary kulot (leniencies) and temporary measures that rabbis are rightly authorizing be balanced with powerful and stirring exhortations about why mesorah (tradition) and continuity matter."

- "When civilian officials prohibit gatherings for health reasons, and they are taking advice from competent health authorities, there should be no question of ignoring these orders."

\section{Conclusions}

As we prepare this article (mid-2021), many people have been vaccinated-fewer Haredi have been vaccinated than Modern Orthodox, but that is offset by much higher levels of COVID among the Haredi, resulting in higher antibody levels (Trencher 2021, p. 5)—and the community has largely come out of "lockdown."

Synagogues have re-opened, with some restrictions, and much of the Orthodox community is still now minimally affected. But the future is unknown. The Orthodox Union's quarterly magazine (first quarter of 2021), featuring the cover story: Life After COVID (https://jewishaction.com/cover-story/life-after-covid/), reflected the continuing uncertainty as to where we are heading: "It is increasingly apparent that the pandemic is not a passing phase but portends a new and yet unknown reality. In our cover story, we asked rabbis and educators to reflect on how COVID has not only impacted our past and present but how it will impact our future. What will the new reality be like once the pandemic is over? What will our shuls look like? What will dating and shidduchim (matchmaking) be like going forward? How can we ... return to normal...but with a renewed sense of purpose and spiritual energy?"

The community has experienced tragic loss, but its sense of connectedness and "Jewishness" remains strong. Prayer has been disrupted, but most look forward its return (perhaps changed). Torah study has continued and, thorough technology, has often been energized. We also found great creativity in children's education. In all, a people that have often struggled through adversity seem to be doing so in this pandemic, and seem to have remained upbeat in the midst of tragedy. Which is as it ever was. 


\section{References}

Klapper, Aryeh. 2020. Beyond pikuach nefesh: Why we need a new and different Torah conversation about life during a pandemic. https://moderntoraleadership.wordpress.com/2020/08/28/beyondpikuach-nefesh-why-we-need-a-new-and-different-torah-conversation-about-life-during-a-pande $\mathrm{mic} /$.

Polack, Martin. 2020. Has the pandemic diminished religious feeling?, The Times of Israel, December 11, 2020. https://blogs.timesofisrael.com/has-the-pandemic-diminished-religious-feeling/.

Trencher, Mark. 2017. The Nishma Research Profile of American Modern Orthodox Jews. http://nishm aresearch.com/assets/pdf/Report\%20-\%20Nishma\%20Research\%20Profile\%20of\%20American\% 20Modern\%20Orthodox\%20Jews\%2009-27-17.pdf.

Trencher, Mark. 2018. Leaving the fold: Dissent from authority in the Orthodox world? In Authority and dissent in Jewish life, ed. Leonard J. Greenspoon, 195-210. West Lafayette: Purdue University Press.

Trencher, Mark. 2020. Nishma Research-Health, Emotional, Financial \& Religious Impacts of the Coronavirus Pandemic in the Jewish Community. Available documents include a full report ("2020 Coronavirus Survey_Complete Report_Nishma Research 06-10-20.pdf”), a summary report (“2020 Coronavirus Survey_Summary Report_Nishma Research 06-10-20.pdf'), the survey questionnaire (“2020 Coronavirus Survey_Questionnaire Only_Nishma Research 06-10-20.pdf”), a summary report of key metrics ("2020 Coronavirus Survey_Dashboard Summary of U.S. Respondent Data_Nishma Research 06-10.pdf"), and a press release announcing the survey ("2020 Coronavirus Survey_Press Release_Nishma Research 06-10-20.pdf”). http://nishmaresearch.com/assets/pdf/ Nishma\%20Research\%20Coronavirus\%20Survey\%2006-10-20.pdf.

Trencher, Mark. 2021. Nishma Research-COVID-19 Attitudes and Vaccine Sentiment in the U.S. Orthodox Jewish Community: Views Among the Chasidish, Yeshivish, and Modern Orthodox Segments. http://nishmaresearch.com/assets/pdf/Nishma-Hatzalah\%20COVID-19\%20Vaccine\%20Sur vey\%20June\%202021.pdf.

Publisher's Note Springer Nature remains neutral with regard to jurisdictional claims in published maps and institutional affiliations.

Mark Trencher is an ordained rabbi, past adjunct professor of mathematics and statistics at three universities, business executive who headed the research departments at two Fortune 200 financial firms, and Jewish communal lay leader (serving as president of a synagogue, Jewish day school, kashrut organization and Jewish film festival). Upon his retirement he established Nishma Research in 2015 as a resource to provide the Jewish community with quality, affordable, needed, independent research. In addition to organizational studies, Nishma has conducted nine broad studies of the Orthodox communities on issues that had not been previously been examined, exploring the community's beliefs, practices, attitudes and changes among all of these attributes. Nishma's goal is to conduct at least $50 \%$ of its work pro bono, and to make all research freely available to the public. 